DOSSIÊ TEMÁTICO: Perspectivas para pensar as cidades: infâncias, educação, democracia e justiça

do https://doi.org/10.22481/praxisedu.v16i40.6888

\title{
O COTIDIANO LÚDICO DOS ENGRAXATES PAULISTANOS
}

\author{
THE LUDIC DAILY LIFE OF THE SHOESHINE BOYS FROM SÃO PAULO
}

LA VIDA COTIDIANA LÚDICA DE LOS LIMPIABOTAS DE SÃO PAULO

\author{
André Augusto de Oliveira Santos \\ Universidade de São Paulo - Brasil \\ José Geraldo Vinci de Moraes \\ Universidade de São Paulo - Brasil
}

Resumo: Desde o século XIX, engraxates ambulantes ocupam as ruas paulistanas para o trabalho e também para a diversão, com brincadeiras e jogos entre um cliente e outro ou após o expediente mais agitado. No início do século XX, os garotos faziam uso de diversos espaços públicos da cidade, como a Praça da Sé e o Largo do Correio, lidando diariamente com a repressão dos órgãos públicos, já que o ofício foi proibido de ser exercido nas ruas em 1901. Ao longo da década de quarenta, o jogo de bola de gude perdeu espaço para uma outra forma de divertimento, a música. A batucada dos engraxates transformava seus próprios instrumentos de trabalho em instrumentos musicais. Hoje, engraxates ambulantes ainda persistem na região central da cidade e em bairros mais distantes, como a região do aeroporto de Congonhas, e seguem colorindo o cotidiano laborioso com brincadeiras e música. A partir de pesquisas em periódicos, fotografias, documentos policiais e sonoros, o artigo identifica e descreve como acontecia no passado e como ocorre ainda hoje o uso dos espaços públicos pelos engraxates paulistanos, assim como seus divertimentos e estratégias para sobreviverem no contexto disputado e violento da cidade.

Palavras chave: Engraxate. História da cidade de São Paulo. História do cotidiano.

\begin{abstract}
Since the nineteenth century, shoeshine boys have occupied the streets of São Paulo for work and also for fun, playing gamesbetween one client and another or after the work was done. At the beginning of the twentieth century, the boys used public spaces in the city, such as Praça da Sé and Largo do Correio, dealing daily with the repression. Throughout the forties, the game of marbles lost space for another form of fun, music, transforming their own work instruments into musical instruments. Today, shoeshine boys still persist in the downtown area and in more distant neighborhoods, such as the Congonhas airport region, and continue to color the busy daily life with play and music. Based on research in periodicals, photographs and police documents, the article identifies and describes how it happened in the past and how the use of public spaces by the shoeshine boys in São Paulo still occurs today, as well as their amusements and strategies to survive in the context of the city.
\end{abstract}

Keywords: Everyday History. History of São Paulo City. Shoeshine boy. 
Resumen: Desde el siglo XIX, los lustrabotas han ocupado las calles de São Paulo por trabajo y diversión, con juegos entre un cliente y otro o después de las horas más ocupadas. A principios del siglo XX, estos niños utilizaban espacios públicos de la ciudad, como la Praça da Sé y el Largo do Correio, a pesar de la represión de las agencias públicas, ya que se les prohibió de trabajaren 1901. A lo largo de los años cuarenta, el juego de canicas perdió espacio para otra forma de diversión, la música. Estos niños convirtió sus propios instrumentos de trabajo en instrumentos musicales. Hoy en día, las pulidoras de calzado aún persisten en el área del centro y en vecindarios más distantes, como la región del aeropuerto de Congonhas, y continúan coloreando la vida cotidiana con juegos y música. Basado en investigaciones en publicaciones periódicas, fotografías y documentos policiales, el artículo identifica y describe cómo sucedió en el pasado el uso de espacios públicos por parte del pulidor de zapatos de São Paulo, así como sus diversiones y estrategias para sobrevivir en el contexto disputado y violento de la ciudad.

Palabras clave: Historia de la ciudad de São Paulo. Historia de la vida cotidiana. Limpiabota.

As crianças do povo, os filhos dos camponeses e dos artesãos, as crianças que brincavam nas praças das aldeias, nas ruas das cidades ou nas cozinhas das casas continuaram a usar o mesmo traje dos adultos: jamais serão representadas usando vestido comprido ou mangas falsas. Elas conservaram o antigo modo de vida que não separava as crianças dos adultos, nem através do traje, nem através do trabalho, nem através dos jogos e brincadeiras. ${ }^{l}$

Visitando a cidade de São Paulo em 1866 o viajante inglês Willian Hadfield percebeu uma cena curiosa que deixou registrada em seu diário: "Esta manhã eu vi um garoto negro na rua empenhado na ocupação de engraxate, com sua pequena caixa e escovas muito além do estilo de Londres" $\left(1869\right.$, p.69) ${ }^{2}$. Nesta época, a cidade que o estrangeiro visitava ainda era um pequeno núcleo urbano acanhado e provinciano. Talvez o conflito entre a atividade eminentemente urbana do engraxate ambulante, típica de metrópoles como Londres e a vida ainda ruralizada de São Paulo o tenha surpreendido. E certamente a presença do pequeno trabalhador negro contribuiu para o espanto. O trabalho ambulante, como o desempenhado pelo engraxate negro que Hadfield observou, era um traço característico da cidade e se manteve com bastante vigor até pelo menos a década de 1950. Durante o longo período do século XIX este tipo de comércio foi desempenhado quase que exclusivamente por mulheres e crianças pobres, que compunham uma parte importante da população paulistana (ODILA,1995).

Quando a capital paulista começou a crescer mais rapidamente, no final daquele século, suas atividades se diversificaram e o número de ambulantes se multiplicou, ganhando ainda maior visibilidade no cenário urbano. Movimentando-se pelas ruas, esses camelôs

\footnotetext{
${ }^{1}$ ARIÈS, 1981, p.67.

${ }^{2}$ This morning I saw a black boy in the street engaged in the occupation of shoeblack, with his little box and brushes very much after the London style. (Tradução dos autores).
} 
exerciam as mais variadas atividades e tinham práticas muito originais, colaborando de vários modos para ativar e caracterizar a vida urbana. O intenso movimento nos espaços públicos atraiu um número ainda maior de meninos, que portando pequenos caixotes de madeira, escovas e latas de graxa, ofereciam o serviço de limpeza e lustração nos sapatos geralmente encardidos pelas ruas empoeiradas. Eles circulavam pelas estações de trem, largos e praças do centro, ofertando o serviço em troca de algumas moedas. Inicialmente, o trabalho era exercido por garotos pobres, negros e mestiços em sua maioria, como o identificado pelo viajante inglês, com o objetivo principal de contribuir na renda familiar. Mas a intensa imigração registrada na cidade, acompanhada da expansão da pobreza e dificuldades no cotidiano, atraíram também os jovens imigrantes recém-chegados. O cronista Antônio Egydio Martins constatou essas transformações ao relatar em suas memórias que

Depois que foi estabelecida a corrente imigratória na antiga Província de São Paulo, começaram, em 1877, ao que parece, a aparecer nas estações da estrada de ferro e nas ruas e largos desta Capital os primeiros engraxates, cuja profissão era exercida por menores italianos de 10 e de 14 anos de idade, recebendo estes em pagamento, pelo seu trabalho, a insignificante quantia de 60 réis (três vinténs). (MARTINS, 2003. p.380)

Os encontros desses jovens de diversas origens criaram nas ruas um inusitado caldo cultural, contribuindo para caracterizar a vida paulistana. Sem ponto fixo ou atividade permanente, os engraxates ambulantes tinham um cotidiano muito peculiar, pois geralmente gozavam longos períodos de intervalo entre um cliente e outro. Esse tempo ocioso era transformado rapidamente em períodos de lazer, usufruídos na forma de músicas, jogos e brincadeiras. Muito ruidosos e já em grande número nas primeiras décadas do século XX, esses garotos foram transformados em problema pelas autoridades municipais, preocupadas em higienizar, organizar e manter o fluxo ininterrupto das ruas e calçadas.

\section{Trabalho e lazer nas ruas}

O encontro de crianças em vias públicas para brincar e se divertir fazia parte da rotina paulistana, causando diferentes reações nos demais habitantes da cidade. Havia quem não encontrasse problema no uso do espaço público por menores para diversões. Outros, porém, se incomodavam principalmente com os ruídos advindos dessas reuniões. Em 1916, na seção “Queixas e Reclamações” d'O Estado de São Paulo, foi publicada reclamação contra garotos 
que "de manhã à noite se aglomeram nas ruas dos arrabaldes, praticando toda a sorte de diabruras num berreiro infernal"3. Os queixosos cobravam das autoridades uma atitude repressora mais atuante já que os guardas civis, despreocupados, apenas observavam o que faziam os moleques, como forma de distração. Para uma parte dos habitantes, assistir a brincadeira das crianças era passatempo, enquanto, para outros, era motivo de queixa. $\mathrm{Na}$ mesma época, outra reclamação semelhante tomou espaço nas páginas do mesmo periódico. $\mathrm{O}$ alvo dos protestos, desta vez, foi um grupo de garotos engraxates da região da rua Vinte e Cinco de Março, que, segundo a versão do jornal, "se entrega a toda sorte de tropelias"4.

Um pouco antes desses episódios, no final do século XIX, quando São Paulo contava pouco menos de cinquenta mil habitantes, brincadeiras de crianças nas ruas já vinham motivando reclamações por parte de moradores. O historiador Boris Fausto (1984, p.82) observou que o jornal Diário Popular deu destaque, em 1886, a um grupo de garotos que praticavam "ações vergonhosas e exercícios de capoeiragem" na ladeira da Tabatinguera, causando inclusive prejuízos a vendedoras ambulantes de frutas. Ainda no final do século XIX, sem motivo aparente um guarda se revoltou e agiu com violência contra um grupo de engraxates que fazia ponto na Estação da Luz. O fato foi noticiado pelo jornal O Estado de São Paulo:

Ontem à tarde, na Estação da Luz, ao chegar o trem de Campinas, um guarda urbano fez proezas. A propósito de uma futilidade esbofeteou a torto e a direito um grupo de meninos engraxates e não contente com isso puxou do refle e esbordoou-os e a alguns indivíduos que se achavam próximos na ocasião de seu ataque de fúria. (O Estado de São Paulo, 01 de novembro de 1888. p. 2)

Apesar da ocorrência de casos de abusos como este, a presença de engraxates nas ruas era tolerada pelas autoridades paulistanas até o início do século XX. Esta situação, contudo, iria sofrer uma reviravolta. Em 1901, o ofício de engraxate ambulante foi proibido de ser exercido nas vias da cidade. Como medida de repressão aos garotos, as autoridades municipais defendiam a multa e a detenção. Foi o que propôs o vereador José Oswald no ano de 1904, em discurso reproduzido também pelo jornal O Estado de São Paulo:

Tendo a câmara proibido na lei do orçamento de 1901 o exercício da profissão de engraxates nas ruas e ainda na lei do orçamento de 1903 a venda avulsa de bilhetes de loterias também nas ruas e praças desta capital, e sendo aquela profissão e este comércio exercidos também por grande número de menores, o meio de coibi-los no caso de desobediência? Não serão a multa e a detenção? (O Estado de São Paulo, 25 de dezembro de 1904, p.3)

${ }^{3}$ O Estado de São Paulo, 13 de julho de 1916. p.4.

${ }^{4}$ Ibidem, 1 de novembro de 1916, p. 5. Segundo o Aurélio, "tropelias" é o mesmo que "travessuras", assim como "diabruras". Ambas estão associadas a brincadeiras de crianças. 
Mas apesar da restrição legal e repressão a que foram submetidos, centenas de meninos continuaram infringindo a lei, burlando o fisco e concorrendo com os lustradores oficiais fixados em salões e cadeiras. E, principalmente, ocupando ruidosamente as ruas da cidade com seu trabalho que muitas vezes se confundia com brincadeiras e lazer. Na segunda década do mesmo século, o fotógrafo italiano Vincenzo Pastore registrou a presença destes menores nas ruas e praças paulistanas, não apenas trabalhando, mas também desfrutando dos momentos de ócio após o expediente ou enquanto esperavam clientes. Naquela época, o divertimento principal dos garotos era o jogo da berlinde ou bolinha de gude.

As fotos de Pastore são um raro testemunho das atividades ao mesmo tempo laboriosas e lúdicas que desenvolviam os meninos engraxates em São Paulo no alvorecer do século XX. A partir delas, podemos notar que as vias da cidade eram um espaço não só de trabalho, mas de reunião e lazer. O dia-a-dia dos meninos era experimentado no espaço urbano, realizando atividades quase sempre em duplas ou grupos. Não há uma só foto, entre as três que retratam especialmente os engraxates ambulantes, na qual um deles aparece sozinho.

A primeira imagem registra o exato momento do exercício da profissão, apresentando dois garotos pequenos, um deles trabalhando e o outro em pé ao lado dele, de costas para a câmera. Este que aparentemente aguarda o amigo realizar o serviço, tem a sua caixa de engraxar nos ombros e um objeto nos braços, que aparenta ser alguma outra caixa de madeira - ou parte de uma caixa. Já o menino que trabalha aparenta ser branco e pousa firme os joelhos na calçada, com um caixote entre suas pernas, engraxando o sapato de um homem elegantemente trajado que descansa seu pé no alto relevo do apetrecho, sentado no banco de uma praça. O engraxador veste uma calça, dobrada até pouco acima dos tornozelos, um casaco, um lenço cobrindo o pescoço e uma boina, traje muito semelhante ao de seu colega. Os dois trazem as cabeças cobertas, mas os pés descalços. A parte mais próxima da calçada na rua atrás dos garotos serve de estacionamento para os famosos tílburis, carros para duas pessoas puxados por um cavalo, um dos principais meios de transporte da época, utilizado principalmente por "retardatários e sobretudo grandes boêmios" (PORTELA, 2006, p.19). 


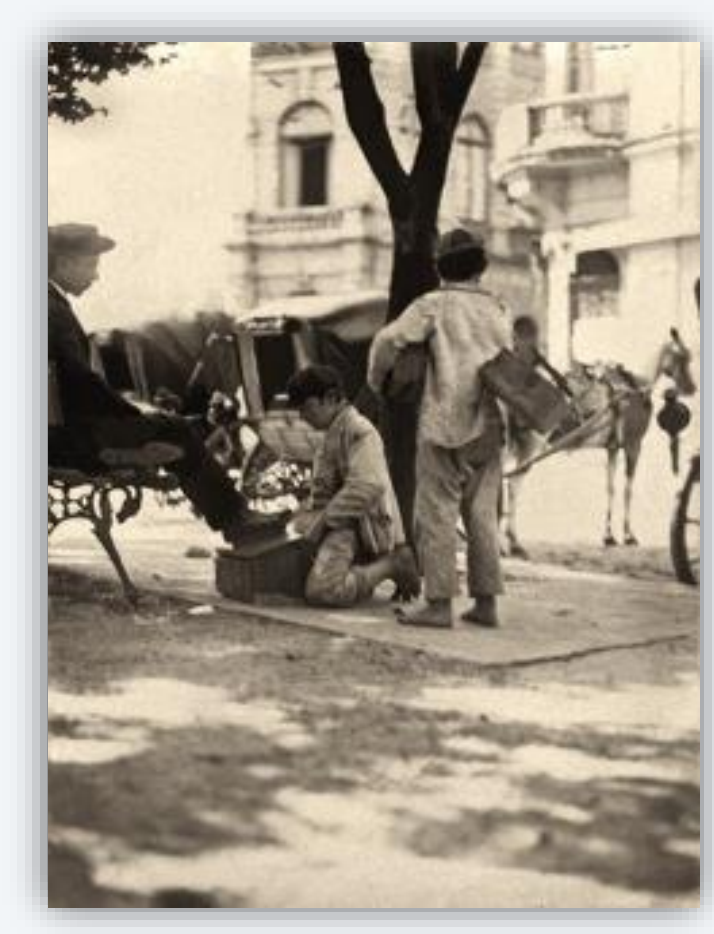

Imagem 1: Fotografia de Vincenzo Pastore.

Década de 1910. Acervo Instituto Moreira Salles

$\mathrm{Na}$ foto seguinte, outra dupla de meninos é flagrada em situação diferente. Os dois estão parados na rua de paralelepípedos bem ao lado da calçada. Não parecem nem um pouco preocupados com o fato de estarem próximos ao lugar onde trafegavam os tilburís e bondes elétricos, que chegaram à cidade em 1900 (PORTELA 2006: p.23). Ao contrário, estão absorvidos com alguma coisa pequena e delicada que o garoto mais alto, com a caixa de engraxar pendurada no ombro, observa e maneja cuidadosamente entre os dedos de suas mãos. O outro garoto, que não porta caixa de engraxate e é um pouco mais baixo, aparentemente tenta ajudar o amigo, também mirando o misterioso e pequeno objeto, erguendo um de seus braços na direção dele. As roupas não diferem daquelas dos engraxates da primeira foto, a não ser pelo colete que o menino de frente para a foto veste. Este, como aqueles, traz a cabeça coberta por chapéu, mas os pés nus. 


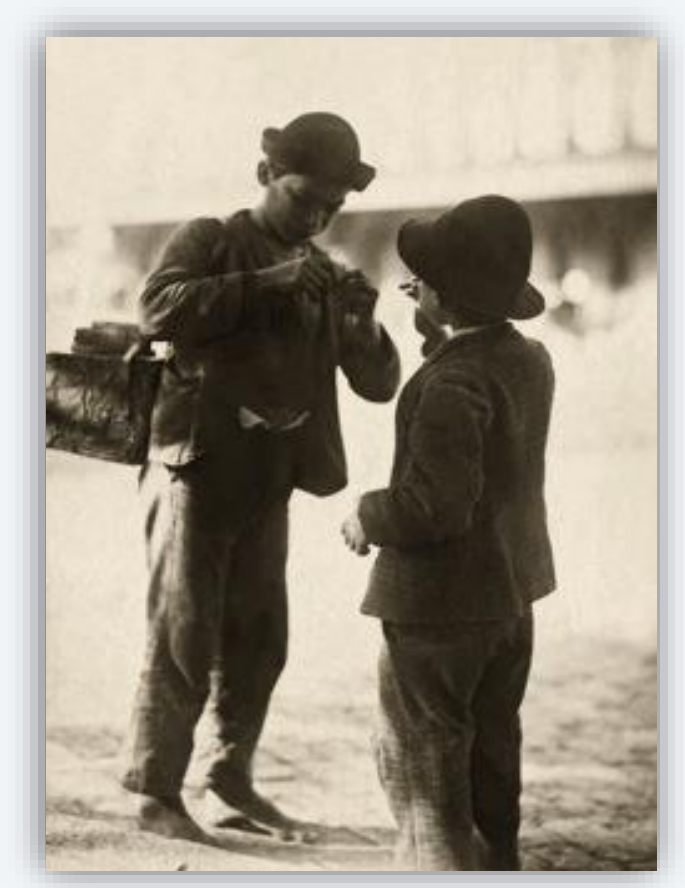

Imagem 2: Fotografia de Vincenzo Pastore. Década de 1910. Acervo Instituto Moreira Salles.

Vincenzo Pastore também flagrou, em uma terceira imagem, um grupo de pequenos engraxates ambulantes na rua, com suas caixas ainda penduradas nos ombros, mas desta vez em um momento de lazer. A fotografia retrata meninos jogando bola de gude em frente a uma casa, em pleno passeio, dando destaque ao caráter lúdico do dia-a-dia de quem desenvolvia trabalhos nos espaços públicos da cidade. A via, de terra, era ocupada por carroças como a que se vê à direita do ajuntamento.

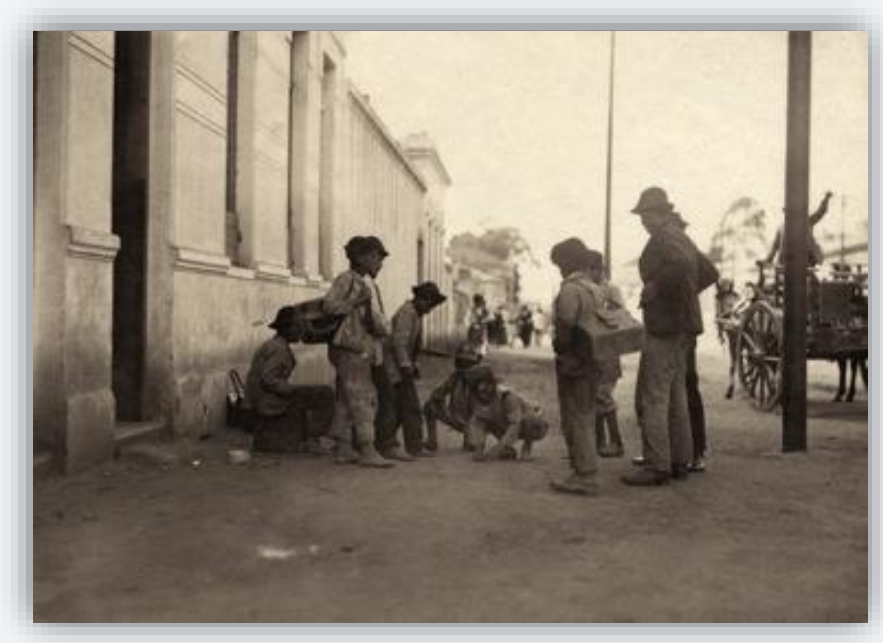

Imagem 3: Fotografia de Vincenzo Pastore. Década de 1910.

Acervo Instituto Moreira Salles. 
A lente de Pastore registrou o encontro de dez jovens parados em frente à porta de uma casa térrea de muro branco e janelas altas. $\mathrm{O}$ grupo forma uma roda, com apenas uma brecha, justamente pela qual o fotógrafo capturou a imagem dos dois jogadores de bola de gude agachados ao centro. O rapaz mais a direita do grupo é o maior, aparentando ser o único adulto. Este homem mais alto, além de outro jovem quase escondido atrás dele, estão calçados, assim como o engraxate de costas em primeiro plano e o outro na mesma linha dele, do outro lado da roda. Todos os demais garotos, que aparentam ter entre 10 e 12 anos, estão com os pés desnudos, configurando-se o grupo de modo a estarem os quatro da direita calçados e os seis da esquerda descalços.

Desde o período colonial, o calçado vinha sendo usado no Brasil como símbolo de diferenciação social. Durante a escravidão, por exemplo, o seu uso dividia os escravos dos homens livres. Gilberto Freyre (1961, p.596) definiu o sapato no século XIX como "sinal de distinção de raça". Apesar das inúmeras mudanças ocorridas no final daquele período, como a abolição da escravidão e a proclamação da república, a lógica persistiu e o sapato continuou sendo um importante símbolo de status na sociedade brasileira que adentrava o século XX. No contexto urbano da cidade de São Paulo, os calçados eram sinal de prestígio e diferenciavam classes sociais (FREHSE, 2011, p. 244). Esta situação só se modificaria, lentamente, a partir da década de 40, com a total popularização dos sapatos. No entanto, mesmo com a crescente disseminação do uso, muitos dos engraxates paulistanos ainda se mantiveram descalços.

Ao observar atentamente a fotografia, nota-se que o menino em primeiro plano, de costas para o fotógrafo, tem uma caixa de engraxate presa por um cinto de couro ao seu ombro. Ele tem uma das mãos escondida no bolso e assiste os dois agachados que jogam bola de gude. Na caixa de engraxate, há um alto relevo em forma de solado de sapato, lugar onde os clientes apoiam o calçado. Outro garoto, o último da esquerda, está sentado sobre alguma caixa que aparenta ser de madeira. Seria uma outra caixa de engraxate? Muito provavelmente. Há outros dois meninos ainda na frente deste, sendo que um deles traz um objeto a tiracolo.

No plano geral, o grupo está relativamente isolado. Entre os garotos e outros transeuntes localizados bem ao fundo, há uma pessoa, que aparenta ser uma mulher, caminhando na direção dos engraxates, mas ainda distante. Não há calçada ou qualquer separação explícita entre os pedestres e a rua. Um poste de energia elétrica aparece como único elemento de ruptura entre os garotos e a carroça parada em um plano um pouco inferior, situação que contrasta com as demais fotografias, em que o espaço de pedestres era sempre separado da rua, com a presença da calçada. Esta foto de Pastore provavelmente foi capturada em algum dos bairros arredores 
ao centro, que ainda não contavam com a estrutura urbana da região central, como o calçamento e as ruas de paralelepípedo. Em 1910, os engraxates ambulantes já se espalhavam além do centro, com seu trabalho e também com suas brincadeiras.

\section{Quando a latinha virou tamborim}

Se na década de 1910 o principal passatempo dos engraxates ambulantes era o jogo da bola de gude; mais tarde, na década de 1940, a brincadeira era outra: cantar sambas e batucar em seus instrumentos de trabalho. Esse ambiente lúdico existente desde o começo do século XX proporcionou um forte vínculo dos engraxates paulistanos com a cultura musical das ruas, marcada pelas mais diversas influências. Sons estrangeiros chegavam com os imigrantes, mas também através dos gramofones e das emissoras de rádio, que possuíam em sua grade de programação atrações voltadas exclusivamente para gêneros importados, como ópera, por exemplo (MORAES, 2000). De modo parecido, a música produzida em outros estados do Brasil, sobretudo no Rio de Janeiro, então Capital Federal, também alcançava o ouvido dos paulistanos através da boca de migrantes, dos gramofones e principalmente pelo rádio, meio de comunicação bastante presente no cotidiano dos cidadãos a partir da década de 1930 (TOTA, 2004). Fora do circuito comercial, a música circulava pela cidade no cantar dos seus moradores e nos encontros informais de músicos amadores. As canções e batuques rurais vindos do interior tinham espaço no calendário festivo, principalmente religioso. Durante o carnaval, chegava a vez dos cordões tomarem a região central e bairros arredores, onde, além de desfilarem, ensaiavam ao longo dos meses que antecediam a folia. Os pregões dos vendedores ambulantes, por sua vez, eram ouvidos diariamente pelos largos, praças, ruas e avenidas.

Nesse turbilhão de sonoridades, timbres, melodias, vozes e sotaques, alguns dos engraxates desenvolveram uma musicalidade bastante singular, marcada por influências de ritmos populares como choro, marcha, maxixe e samba. Usavam, muitas vezes, suas habilidades musicais para espairecer os clientes ou até fazer assunto para uma conversa. Esta característica marcante foi percebida pelo colunista Juca Pato ${ }^{5}$ enquanto passava pelo então Largo da Sé, em 1927:

Ontem, ao largo da sé, observamos uma cena curiosa, típica: - um cavalheiro, muito bem posto, sentou-se a uma cadeira de engraxate, e esperou que o garoto lhe polisse as botinas.

${ }^{5}$ Personagem fictício criado pelo jornalista Belmonte para a sua coluna no jornal Folha da Manhã. 
Enquanto isso, aguardando o duzentão da 'gorja', o moleque, contente, assobiava o 'Cristo nasceu na Bahia'.

O freguês 'gozava' a música.

De súbito, o 'oficiale' o advertiu:

- Pronto, freguês!

- Quanto custa?

- Trezentão...

- Você tem troco para 500 reis?

- Que troco deseja o sr.? E a 'gorja'?

(Folha da Manhã, 29 de janeiro de 1927. p.3)

Atentos às referências musicais que circulavam pela cidade, os garotos reproduziam a melodia no assobio como uma estratégia para entreter o cliente que aguardava o término do serviço, tanto que rendeu comentários por parte do cavalheiro. A predileção do engraxate pelo maxixe Cristo nasceu na Bahia não foi à toa. Música dos compositores Sebastião Cirino e Duque, a canção foi gravada por Arthur Costa em 1926, tornando-se um acontecimento carnavalesco no ano seguinte. Mas o engraxate assobiava a canção em janeiro, anteriormente à Festa do Momo, como que antecipando o sucesso. Na realidade, antes de explodir no carnaval, a música já era bastante conhecida nas ruas, pois vinha tendo destaque como um dos números do Teatro de Revistas Tudo Preto, dirigido por De Chocolat ${ }^{6}$ e estrelado pela Companhia Negra de Revistas, formada exclusivamente por atores negros. O espetáculo estreou em 31 de julho de 1926, no Rio de Janeiro e Cristo nasceu na Bahia fez grande sucesso, o que a levou a ser gravada, permitindo que chegasse aos ouvidos do engraxate paulistano da reportagem. A orquestra da companhia carioca Tudo Preto contava com a regência de Pixinguinha e quem assinou a autoria das músicas do espetáculo foi justamente Sebastião Cirino ${ }^{7}$.

Personagens musicais de uma cidade sonora, os engraxates paulistanos do começo do século XX não se contentavam em apenas reproduzir, por assobio, as músicas que ecoavam das rádios. Durante os festejos carnavalescos, alguns formavam pequenos conjuntos e saiam tocando instrumentos pelas ruas dos bairros. Também não deixavam de brincar, dançando ou batucando, nas agremiações carnavalescas paulistanas, como os antigos cordões e as novíssimas escolas de samba. É o que informa uma reportagem publicada na capa do jornal Folha da Noite, cujo mote era o modo como o paulistano iria brincar o carnaval de 1933. O repórter, após colher depoimentos de um jornalista, um banqueiro, um doutor e todos afirmarem que planejavam descansar no feriado, finalmente encontrava alguém disposto a cair na folia, justamente um

\footnotetext{
${ }^{6}$ Artista, cantor e compositor baiano radicado no Rio de Janeiro. Em “Tudo Preto", além de desempenhar o papel de protagonista, estreava como diretor.

${ }^{7}$ Curiosamente, o compositor mineiro, quando adolescente, trabalhou como engraxate nas ruas do Rio de Janeiro, antes de ser preso por vadiagem, aprender a tocar pistom e trompete no presídio e passar a dedicar-se à música.
} 
engraxate. Além de se divertir "fazendo barulho" com a sua turma de amigos, o jovem brincava carnaval com o cordão do Vai-Vai, que apesar dos apenas cinco anos de existência, já era bastante conhecido no bairro de origem, o Bexiga. A agremiação costumava realizar bailes em sua sede durante todos os dias do feriado momesco ${ }^{8}$. O esperto engraxate, cujo nome a reportagem não revela, aproveitava:

\section{UM ENGRAXATE QUE 'É MESMO DO AMOR' E 'VAI ARRASTAR A SANDÁLIA QUE NÃO É VIDA'}

Desanimado já, o repórter sentou-se á cadeira de um engraxate. Um moleque vivaz, olhos negros, cabelos desgrenhados - fagulha, irrequieta, que saltou do dínamo imenso da metrópole.

- Você no carnaval...

- Vou fazer 'barulho', moço! A turma já arranjou um violão, uma clarineta, um violino, um cavaco e um banjo. Vai ser 'daqui' o 'choro' (passou o braço por detrás do pescoço e segurou a ponta da orelha). Há duas semanas que nós estamos ensaiando. Vou dançar, também.

- Onde?

- No 'Vai-vai'. Aquilo é que é clube da 'virada'. A gente dança até a manhã seguinte. 'Arrasta a sandália' que não é vida...

- 'Vai vai'... onde é...

- No Bexiga. 'Ué', o senhor não conhece? Ah! O senhor não sabe o que é coisa boa! Esse negócio de Odeon, Esplanada, não vale nem uma valsinha, no 'Vaivai'...

(Folha da Noite, 25 de fevereiro de 1933. $2^{\text {a }}$ Edição. Capa.)

Além de organizar bailes carnavalescos, o Vai-Vai também desfilava fazendo música pelas ruas. A agremiação, que nasceu como time de futebol de várzea em 1928, oficializou-se como cordão carnavalesco em 1930. Em 1933, portanto, já estava oficialmente em seu segundo ou terceiro carnaval. O pequeno trabalhador ficou surpreso com o fato do jornalista não conhecer o grupo e para convencê-lo de que as noites no bairro do Bexiga eram as melhores, em um exercício de alguém muito habituado a uma boa discussão, compara aquele clube aos bailes mais conhecidos da cidade, frequentados pela elite paulistana, o Odeon e o Esplanada.

A cadência musical escolhida para o festejo foi a do ritmo tipicamente urbano do choro. Embora genérico, no sentido de abranger várias rubricas musicais, o choro era, já àquela altura, uma denominação conferida às canções executadas pelos conjuntos de músicos populares formados basicamente por instrumentos de cordas e sopro que deram, no final do século XIX, formato ao gênero original do Rio de Janeiro ${ }^{9}$. Sob esta denominação, abarcam-se ritmos

\footnotetext{
${ }^{8}$ Bem mais tarde, em 1972, o grupo, que teve origem em um time de futebol de várzea, se transformaria em Escola de Samba, formato com o qual desfila até hoje.

9“'De modo geral, o choro iniciou seu processo de consolidação de gênero musical urbano por volta de 1870, ainda como forma dos músicos populares do Rio de Janeiro interpretarem valsas, habaneras, tangos e sobretudo polcas,
} 
rotulados como polca e valsa, por exemplo. Em São Paulo, o choro se popularizaria na virada do século XIX para o XX, executado por grupos de músicos amadores que empregavam o tipo de instrumentação descrito pelo engraxate na reportagem (MORAES, 1995. p.140). O primeiro cordão carnavalesco de São Paulo, o Grupo Carnavalesco da Barra Funda, inclusive, teve origem em um grupo de músicos que tocava choro. $\mathrm{O}$ depoimento ganha ainda mais sentido se considerarmos as atividades musicais desempenhadas por membros do cordão do Bexiga fora do contexto carnavalesco. De acordo com Simson (2007, p.156), "músicos que integravam o Vai-Vai costumavam tocar em conjunto nos grupos de choro ou serenata e nas festas em casas de família, muito comuns nessa época no bairro do Bexiga".

A música de tradição oral no Brasil sempre foi um dos principais canais de interlocução cultural, especialmente entre os estratos mais pobres da população (MORAES; MACHADO, 2011. p.173). E foi justamente através da musicalidade que transbordava das ruas paulistanas, permeada por canções do rádio, grupos carnavalescos, cantos e quadras de outros vendedores ambulantes, que os engraxates encontraram uma brecha para expressão, modo de compartilharem entre si, mas também com a sociedade, suas experiências, anseios e angústias. Os encontros para o batuque, realizados cotidianamente e de improviso, nos momentos de intervalo, entre um cliente e outro ou após o expediente, além de possuir uma evidente característica lúdica, atrelada quase sempre à dança e à brincadeira, constituía-se como um uso original do espaço urbano, uma prática cultural que formava a identidade daquele grupo, modo de estarem no mundo, comunicarem com os demais moradores da cidade e narrarem experiências do cotidiano ${ }^{10}$. À roda inicial formada pelos pequenos trabalhadores percutindo seus próprios instrumentos de batente, outros indivíduos se ajuntavam, para apenas apreciar o batuque ou efetivamente participar da atividade. Entre o grupo, alguns também eram compositores e aproveitavam o momento para apresentar seus sambas ali mesmo nas esquinas, largos e praças da cidade.

a partir de pequenos conjuntos constituídos por violões e cavaquinhos, incorporando-se mais tarde algum instrumento de sopro, principalmente flauta." (MORAES, 1995. p.138 e 139)

${ }^{10}$ Empregamos aqui o conceito de "prática cultural" de Chartier (2002), conforme proposto por Moraes (2005, p.51): "De seu lado, o historiador Roger Chartier rejeitou a princípio a oposição a priori entre cultura popular/ erudita, mas não o conflito. Para fugir das armadilhas da 'tirania do social' (a cultura compreendida como mero reflexo da sociedade), que determinaria os limites e características de uma dada cultura e dos conflitos, ele sugeriu o conceito de 'prática cultural', composto pelas categorias de 'representação' e 'apropriação'. A representação pode articular até três formas de relação com o mundo social: a classificação e delimitação das inúmeras produções intelectuais criadas contraditoriamente pelos diversos grupos sociais; as práticas que visam fazer reconhecer uma identidade social, exibir uma maneira própria de estar no mundo e significar simbolicamente uma posição; as formas institucionalizadas às quais seus representantes (individuais ou coletivos) marcam e perpetuam a existência do grupo, classe e comunidade". 


\section{Samba no largo do Correio}

O fato de que a prática musical dos engraxates paulistanos esteve estritamente ligada à oralidade impôs dificuldades ao seu registro escrito e/ou sonoro. Consequentemente, a documentação existente a respeito dessa tradição não é abundante. Dos esparsos registros escritos que restaram sobre essa atividade, por sua vez, uma parte advém de crônicas escritas por jornalistas que se depararam com o encontro e registraram em jornais ou revistas, como fez o radialista Túlio de Lemos para a revista Planalto em 1941. Publicada no exemplar número 8 do quinzenário de cultura, a reportagem "O Canto dos engraxates Paulistanos" narra a experiência do jornalista de observar com atenção um encontro entre engraxates ambulantes negros, reunidos na avenida São João após mais um dia de trabalho. O divertimento dos rapazes consistia em cantar sambas ao som do batuque produzido nos próprios instrumentos de trabalho:

Dentro da tumultuosa noite paulistana os engraxates cantam. Isso acontece quase todas as noites, na esquina da Avenida São João com a Praça do Correio, na parte que inicia o parque Anhangabaú.

À margem da ruidosa sinfonia urbana, feita da trepidação dos bondes, do buzinar dos automóveis, da gritaria dos jornaleiros e do vozerio das multidões apressadas, nasce humilde absorto e bonito, o canto dos engraxates negros. (Revista Planalto, ano I, número 8, 1 de outubro de 1941, p.7.)

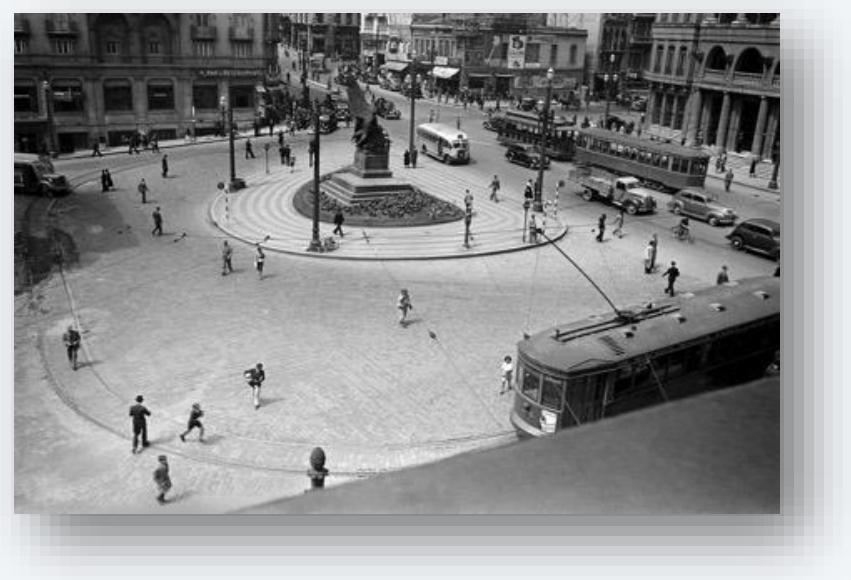

Imagem 4. Largo do Correio na década de 1940.

Fotografia de Hildegard Rosenthal.

O espaço escolhido para a reunião certamente não era estranho aos pequenos trabalhadores. Transformada em avenida após uma grande reforma entre 1920 e 1922, a avenida São João era uma das vias mais importantes da cidade e tornou-se um dos locais prediletos dos engraxates para exercer o ofício. A região, naquele período, se constituía como novo centro de 
São Paulo e da sua boêmia. Os principais cinemas se achavam lá, inclusive o famoso Cine Metro, localizado na altura da Praça da República, inaugurado em 1938. À noite, porém, a área via reduzida uma parte do seu movimento, deixando espaço para o encontro dos engraxates, que se juntavam com menos chances de serem incomodados ou perturbarem os transeuntes. $\mathrm{O}$ lugar ideal para o samba era justamente o Largo do Correio, onde a São João encontrava o Parque do Anhangabaú, espaço conhecido informalmente, entre os engraxates, como "prainha". Coincidentemente ou não, o Largo do Correio, construído após a demolição do antigo Mercado São João, era justamente ponto de partida de onde saíam cortejos carnavalescos durante as festas do momo naquela época. Além de tudo, como pode ser observado na fotografia de Rosenthal, era uma área bastante ampla, o que possibilitava a fuga dos engraxates caso a polícia fosse avistada.

A posição e disposição dos garotos também não passaram despercebidas aos olhos do indiscreto espectador. O jornalista descreve assim o modo como os engraxates ocupavam a praça:

[...] uns quinze pretos sentados no chão, rodeando um cantor, preto também, que, de pé, enviava a sua voz para o alto, com a cabeça bem erguida, os olhos semicerrados e uma expressão de dor no rosto retinto e brilhante. Os que estavam sentados formavam a orquestra; sem dúvida a mais original das orquestras; composta exclusivamente de instrumentos de percussão; (Revista Planalto, ano I, número 8, 1 de outubro de 1941, p.7.)

A descrição de Lemos apresenta uma cena inversa à registrada na foto do italiano Pastore: se lá os dois meninos ao centro estavam agachados para jogar bolinha de gude e os demais formavam a roda em pé, aqui o personagem cantor ao centro é o único em pé, rodeado por batuqueiros sentados. Após descrever a disposição do grupo, o radialista prossegue com sua narrativa apresentando a referida orquestra percussiva:

Eu vos direis que os instrumentos eram bem espantosos; o mais importante era uma dessas caixas usadas pelos engraxates ambulantes [...] Batendo-se-lhe na superfície lisa emitirá um som relativo ao dos bombos, som que uma habilidosa pressão das mãos do tocador modificará para mais claro ou mais escuro; o dispositivo no qual se apoia o sapato a engraxar produz por sua vez outro som, assim como cada parte da caixa realiza um som particular, coisa que por si só engendraria todo um complexo sistema orquestral. Mas não fiquemos na 'caixa', pois que outras delícias vos esperam. O vidro vazio que costuma conter a água que dá brilho à engraxadela, eis outro instrumento de alto valor no fabuloso conjunto; solicitados por mãos carinhosamente musicais, os pobres vidros cantam lindamente. E o que me direis dessas tão conhecidas latinhas de 'pastas para calçados?' Pois eu vos afirmo que se possuirdes uma poética alma de engraxate paulistano podereis transformá-las 
em magníficos instrumentos de música; a lata propriamente dita tem um timbre seco e agudo, de pouca ressonância, ao passo que a tampa oferece um som brilhante, ligeiramente mais grave; mas eis que, fechada, cheia ou vazia, a incrível latinha realiza o milagre de muitos outros sons. Também a escova tem uma função sonora. Enfim: todos os apetrechos de trabalho dos engraxates, em contato com a musicalidade desses trabalhadores humildes, são elevados a condição de instrumentos de música. (Revista Planalto, ano I, número 8,1 de outubro de 1941, p.7).

A expressão dos batuqueiros também não passa despercebida pela descrição:

O Samba que estão executando não é triste, até é bem buliçoso; mas a expressão dos músicos é grave, quase religiosa. Um preto de coco rapado, sentado na soleira de uma porta, está se contorcendo na execução de um recoreco que resulta do atrito de uma escovinha de tingir sapatos sobre as letras em relevo de um vidro vazio; outro se debruça carinhosamente sobre a sua caixa, de onde arranca roncos que ecoam em nossos estômagos e vibram em nossos nervos. (Revista Planalto, ano I, número 8, 1 de outubro de 1941, p.7).

Túlio de Lemos destaca a capacidade e habilidade dos engraxates em adaptar seus utensílios criados para o trabalho em instrumentos musicais. Esta ressignificação do objeto originalmente dotado de uma função laboriosa em artefato musical, realizada no cotidiano, configura-se um modo dos engraxates transformarem diariamente "a ordem efetiva das coisas" - para usar a expressão de Certeau (1994, p.88) - e assim, de modo extremamente criativo, inventarem uma estratégia para resistir à moral do trabalho imposta aos habitantes da cidade moderna. Os utensílios, símbolos de uma identidade laboriosa, transformavam-se em instrumentos para o lazer.

Para realizar a transformação nos objetos, era necessária uma aguçada capacidade de percepção e assimilação musical. Como já mostramos, acontecia de engraxates circularem pelos grupos carnavalescos da cidade e em reuniões improvisadas de músicos amadores. Por meio de um aprendizado que se dava quase sempre de modo informal, estas vivências tornavam possível aos garotos reproduzirem, nos seus próprios instrumentos de trabalho, os sons e toques que ouviam no rádio ou observavam em festas populares, sempre admitindo uma brecha para a criação individual e o improviso. E eles eram capazes das mais extraordinárias soluções. $\mathrm{Na}$ descrição realizada por Túlio de Lemos, ele identifica, por exemplo, diversos timbres. A formação musical do radialista permitiu que ele apresentasse nos pormenores os instrumentos, até com alguma didática, distinguindo entre os diferentes timbres e funções de cada um dos objetos. Se a caixa de madeira era capaz de realizar o som grave da marcação, de acordo com a musicalidade do engraxate ela atuava também em timbres médios, constituindo-se, por isso, no 
mais importante e completo instrumento da orquestra, como destacou o repórter. A escova, atritando contra letras em relevo, produz som que se aproxima do instrumento reco-reco, típico do samba, preenchendo todos os tempos do ritmo, com acentuações ao gosto do músico. $\mathrm{O}$ caminho ficava livre, assim, para que a latinha e sua tampa, instrumentos que propiciam timbres mais agudos e secos, desempenhassem função semelhante à dos tamborins, realizando os floreios e síncopes mais característicos do ritmo. Não há instrumento percussivo propriamente dito, tampouco instrumento harmônico, como o cavaquinho ou o violão, que formavam os conjuntos de sambas à época.

\section{Os Meninos de Congonhas}

Ao final da década de 1940, a região central e a Praça da Sé, um dos principais redutos de engraxates, passaram por intensas reformas que fizeram diminuir o número de ambulantes na região. $\mathrm{O}$ triunfo do modelo de cidade em permanente movimento fez com que as ruas e calçadas passassem cada vez mais a serem vistas como espaços de circulação intensa e que, portanto, deveriam ser deixadas livre, sem obstáculos, para a passagem. Pouco depois, outro fato que provavelmente contribuiu para o declínio do número de engraxates foi a popularização do tênis, a partir da década de 1950. Até então de uso restrito às práticas esportivas, o tênis tornou-se presença permanente nas novas culturas da juventude que emergiram à época e também um dos símbolos da propagação da cultura norte-americana. A expansão de seu uso diminuiu gradativamente os números de sapatos circulando pela cidade e, consequentemente, a necessidade dos engraxates. Mas apesar de estarem em menor número, eles não deixaram jamais de compor a paisagem visual e sonora da Paulicéia. A tal ponto que ainda hoje meninos e suas caixas persistem em alguns espaços públicos da cidade e continuam chamando a atenção de jornalistas que insistem em dedicar-lhes páginas de jornais. E é interessante notar que alguns elementos do cotidiano desses jovens trabalhadores permanecem muito semelhantes aos dos jovens daquela longínqua década de 1940. Embora o ambiente de trabalho e seu entorno sejam completamente diferentes, os engraxates contemporâneos brincam e fazem música, como fizeram os do passado.

Em 15 de setembro de 2013, por exemplo, a Folha de São Paulo estampou na capa uma foto de três garotos que trabalhavam como engraxates ambulantes no aeroporto de Congonhas, região sul de São Paulo. Cabeças erguidas, caixas de madeira nos ombros, os jovens caminhavam de costas para o fotógrafo, vestindo bermudas e camisetas. A legenda, intitulada 
"Vai graxa?", informava que durante a disputa por clientes, ganha a vez "aquele que grita primeiro 'botequim"”. Tratava-se da chamada para uma reportagem intitulada "Os meninos de Congonhas", do caderno Cotidiano, sobre aquele grupo de pequenos trabalhadores.

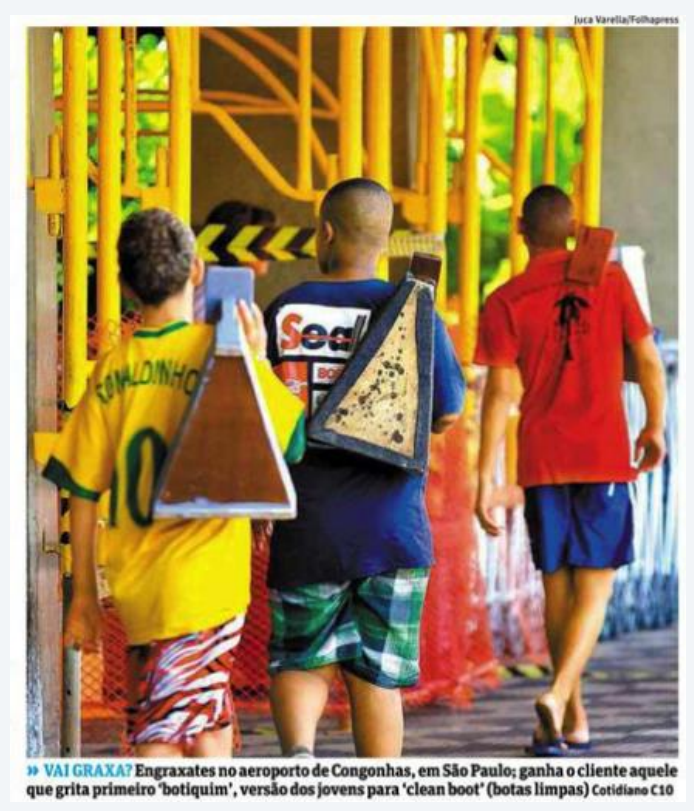

Imagem 5: Folha de São Paulo, 15 de setembro de 2013. Capa. Foto: Juca Varella/ Folhapress.

Dentro do jornal, mais duas imagens, uma no topo da página e outra ao centro. Ambas retratam meninos nas imediações do aeroporto, portando caixas de engraxar. Os rostos e nomes não são revelados, apenas as idades: 10 e 13. Segundo o jornal, "De segunda a sexta, ao menos dez garotos de 10 a 17 anos trabalham, das $7 \mathrm{~h}$ às $21 \mathrm{~h}$, em diferentes turnos". Alguns começaram a lustrar sapatos por influência do irmão mais velho ou dos amigos também engraxates, mas nenhum deles pretendia ficar muito tempo ali, devido ao preconceito em relação à profissão.

O lucro obtido com o trabalho era repartido em casa e o que sobrava, cada um gastava como precisava. De acordo com um dos garotos, quando o movimento era bom, chegava a fazer até 50 reais em um dia. Quando não havia clientes, por sua vez, o jeito era arrumarem juntos um passatempo:

Se o movimento no aeroporto começa a cair, os meninos aproveitam a 'folga' para o bate-moeda. A brincadeira consiste em jogar, com força, uma moeda sobre a outra para tentar virar a que está no chão. Vence o primeiro que conseguir virar a moeda. (Folha de São Paulo, 15 de setembro de 2013. Caderno Cotidiano, p.10). 
Outro engraxate entrevistado para a reportagem, ao invés da brincadeira com moedas, escolheu como passatempo a música:

Paulo [nome fictício] é de pouca prosa. Prefere música. Improvisa raps na caixa de engraxar.

As letras falam da repressão dos seguranças do aeroporto contra os garotos, do sonho em morar numa mansão no Morumbi e do comportamento das meninas da favela onde moram, a Morro do Piolho (zona sul da capital). (Folha de São Paulo, 15 de setembro de 2013. Caderno Cotidiano, p.10).

Às vezes, os meninos eram visitados por assistentes sociais contratados pela Infraero, que faziam um serviço de identificação e cadastramento para "proibir trabalho infantil” no local. A estatal possuía um projeto de jovens aprendizes que, segundo afirma, havia matriculado seis dos garotos. Atraídos ao aeroporto pela presença de executivos chegando à cidade para reuniões de negócios, onde estar com os calçados brilhando é imperativo, os engraxates preferiam atender clientes vindos do exterior, de quem cobravam mais caro pelo serviço. Acostumados a atender estrangeiros, a inventividade fez com que, através de uma corruptela sonora, a expressão estrangeira "boot clean" alterasse completamente o seu sentido e se transformasse em "botequim". Utilizada como uma espécie de código, a expressão serve para garantir a vez de trabalhar àquele mais atento aos possíveis clientes, pois a regra do jogo determina que presta serviço o engraxate que, ao avistar um cliente, grita "botequim" antes dos outros.

Como os "meninos de Congonhas", os pequenos engraxates do passado também andavam em grupos e, quando faltava freguesia, arrumavam passatempos para amenizar o cotidiano laborioso. No início do século XX, uma das brincadeiras era a bolinha de gude. Mais tarde, na década de 1940, um dos principais divertimentos consistia em cantar sambas e batucar nos utensílios de trabalho. Em roda, os engraxates se reuniam nas esquinas da região central, principalmente na Praça da Sé e no Largo do Correio, para cantar ao som do ritmo produzido nas suas caixas, latinhas e escovas. Muitas das canções que ecoavam eram compostas pelos próprios garotos, em letras que, à maneira dos raps entoados pelos engraxates contemporâneos de Congonhas, versavam sobre o cotidiano laborioso e a repressão a que estavam submetidos. Colorir com brincadeiras e música o cotidiano consiste em um modo de subverter a ordem do trabalho, do elemento que os tornava adultos, para, através da brincadeira, voltarem a ser novamente crianças. 


\section{REFERÊNCIAS}

CERTEAU, Michel de. A invenção do Cotidiano. Petrópolis (RJ): Vozes, 1994. P. 88.

CHARTIER, Roger. A História Cultural: entre práticas e representações. $2^{\mathrm{a}}$ Edição. Lisboa: Difel, 2002.

COMO vai passar o carnaval? Jornal Folha da Noite. $2^{\text {a }}$ Edição. São Paulo. 25 de fevereiro de 1933. Capa.

DESABAFOS de Juca Pato. Jornal Folha da Manhã. São Paulo, 29 de janeiro de 1927. p.3

DIAS, Maria Odila Leite da Silva. Quotidiano e Poder em São Paulo no Século XIX. São Paulo: Brasiliense, 1995.

FAUSTO, Boris Crime e Cotidiano. A criminalidade em São Paulo (1880-1924). São Paulo: Brasiliense, 1984.

FREHSE, Fraya. Ô da Rua! O Transeunte e o Advento da Modernidade em São Paulo. São Paulo: Editora da Universidade de São Paulo, 2011.

FREYRE, Gilberto. Sobrados e Mucambos. Rio de Janeiro, José Olympio Editora, 3a Edição, 1961. [1a ed. 1936].

HADFIELD, William. Brazil and The River Plate in 1868. Londres: Bates, Hendy and Co. 1869.

LEMOS, Túlio de. O Canto dos Engraxates Paulistanos. Revista Planalto, São Paulo, ano 1, número 8,1 de outubro de 1941 .

MARTINS, Antonio Egydio. São Paulo Antigo: 1554 a 1910. São Paulo: Paz e Terra, 2003.

MORAES, José Geraldo Vinci de. Metrópole em Sinfonia: historia, cultura e música popular na São Paulo dos anos 30. São Paulo: Estação Liberdade/ Fapesp, 2000.

MORAES, José Geraldo Vinci de. Sonoridades Paulistanas. Final do século XIX ao início do século XX. Rio de Janeiro: Funarte, 1995. Pp.138 e 139.

MORAES, José Geraldo Vinci de e MACHADO, Cacá. Música em Conserva. Revista Auditório. São Paulo. N.1. P. 163 - 183, 2011. P.173.

MORAES, José Geraldo Vinci de. "Modulações e Novos Ritmos na Oficina da História". Revista Galega de Cooperación Científica Iberoamericana. Espanha. N.11, 2005. P. 51.

NOTÍCIAS diversas - Câmara Municipal. Jornal O Estado de São Paulo. São Paulo 25 de dezembro de 1904, p.3

OLIVEIRA. Roberto de. Os meninos de Congonhas. Jornal Folha de São Paulo. São Paulo. 15 de setembro de 2013. Caderno Cotidiano, p.10. 
PORTELA, Fernando. Bonde o saudoso paulistano. São Paulo: Editora Terceiro Nome, 2006.

QUEIXAS e Reclamações. Jornal O Estado de São Paulo. São Paulo, 13 de julho de 1916. p.4.

QUEIXAS e Reclamações. Jornal O Estado de São Paulo. São Paulo, 1 de novembro de 1916, p. 5.

SIMSON, Olga Rodrigues de Moraes. Carnaval em Branco e Negro: Carnaval Popular Paulistano: 1914-1988. Campinas: Editora da Unicamp; São Paulo: Editora da Universidade de São Paulo; Imprensa Oficial do Estado de São Paulo, 2007.

VAI graxa? Jornal Folha de São Paulo. São Paulo.15 de setembro de 2013. Capa

TOTA, Antonio Pedro. "Rádio e modernidade em São Paulo". História da Cidade de São Paulo, v.3: a cidade na primeira metade do Século XX. Paula Porta (org). São Paulo: Paz e Terra, 2004.

\section{SOBRE OS AUTORES:}

\section{André Augusto de Oliveira Santos}

Universidade de São Paulo. É aluno de doutorado da Universidade de São Paulo - Brasil; Programa de Pós-Graduação em História Social; Possui bolsa de Pesquisa Grupo de Pesquisa Entre a Memória e a História da Música. E-mail: andreaosantos@usp.br.

iD http://orcid.org/0000-0003-1466-9656

\section{José Geraldo Vinci de Moraes.}

Universidade de São Paulo. Possui pós-doutorado pela Université Paris-Ouest Nanterre, Professor livre docente da Universidade de São Paulo, Coordenador do Grupo de Pesquisa Entre a Memória e a História da Música e membro do Ludens - USP (Núcleo Interdisciplinar de Estudos Sobre Futebol e Modalidades Lúdicas). É pesquisador CNPq 2 CA-AC desde 2010. Email: zgeraldo@usp.br

iD http://orcid.org/0000-0002-0501-2102 